\title{
CALCULATION OF INTRACELLULAR PH FROM THE DISTRIBUTION OF 5,5-DIMETHYL-2,4-OXAZOLIDINEDIONE (DMO). APPLICA- TION TO SKELETAL MUSCLE OF THE DOG*
}

\author{
By WILLIAM J. WADDELL AND THOMAS C. BUTLER \\ (From the Department of Pharmacology, University of North Carolina School of Medicine, \\ Chapel Hill, N. C.)
}

(Submitted for publication October 6, 1958; accepted January 2, 1959)

Estimations of hydrogen ion activities in the interior of cells have been attempted through a number of different experimental approaches. The methods that have been employed are of several general types: measurements on preparations of broken cells, measurements on fluid withdrawn from cells, observations with visible indicators, measurements with micro-electrodes introduced into cells, measurements of the intracellular and extracellular concentrations of weak organic acids and bases, and calculation of the balance of ionic charges. The last named method has been proposed by Conway (1). The other methods are discussed in the review of Caldwell (2), which contains a tabulation of the results of measurements on various types of cells with different experimental methods. Some of the methods that have been used are of quite limited applicability, and most of the values arrived at by any of the methods are subject to question.

Potentially, the method utilizing the distribution of weak organic acids and bases has a wider range of applicability than the other methods, and it is not subject to some of the theoretical objections that can be raised to other methods. There is a great deal of evidence that membranes of animal and plant cells in general are characterized by free permeability to the undissociated forms of weak organic acids and bases and by impermeability or apparent impermeability to the ionic forms. If the $\mathrm{pH}$ of the interior of a cell differs from that of the external medium in contact with it, there will be a corresponding difference in the concentration of an organic ion. The assumption

* This investigation was supported in part by a research grant (B-384) from the National Institute of Neurological Diseases and Blindness, National Institutes of Health, Public Health Service. that the undissociated form of an acid or base is in equal concentration on the two sides of the cellular membrane permits the calculation of intracellular $\mathrm{pH}$ from measurements of extracellular $\mathrm{pH}$ and the extracellular and intracellular concentrations of the acid or base. In most of the work that has hitherto been done based on this principle, carbon dioxide has been the compound used as the indicator. It is assumed that the cellular membrane is permeable to carbon dioxide and that the tension of carbon dioxide inside the cell is equal to that measured in an external phase in equilibrium with the cell. The total carbon dioxide released from the cells after addition of acid is determined and is assumed to come from dissolved carbon dioxide, carbonic acid and bicarbonate ion. These data are sufficient for calculation of the intracellular concentration of bicarbonate ion and of the intracellular $\mathrm{pH}$. The $\mathrm{pK}_{1}^{\prime}$ of carbonic acid is such that its ionization should furnish a sensitive measure of intracellular $\mathrm{pH}$. However, the validity of $\mathrm{pH}$ measurements made with the carbon dioxide method has been questioned. Conway and Fearon (3) concluded from their experiments that a large part of the carbon dioxide released from muscle cells by acid is derived from acid-labile material other than bicarbonate. If this should be so, the $\mathrm{pH}$ values calculated from the assumption that all acid-labile carbon dioxide comes from bicarbonate would be seriously in error.

In the course of a study of the tissue distribution of 5,5-dimethyl-2,4-oxazolidinedione ("DMO"), the product of metabolic N-demethylation of the antiepileptic agent, trimethadione (Tridione ${ }^{(B)}$ (4), we have found that the attributes desirable in a compound to be used for the measurement of intracellular $\mathrm{pH}$ are combined to an almost ideal degree in DMO. These properties will be dis- 
cussed in detail below. The advantages of DMO over carbon dioxide are in the facility of analytical determination and in the absence of any question as to the chemical identity of the material determined by the analytical procedure. The present report comprises a theoretical consideration of the estimation of intracellular $\mathrm{pH}$ from the distribution of acids and bases and an application of the DMO method to the estimation of intracellular $\mathrm{pH}$ of skeletal muscle of the dog under various conditions. We have been particularly interested in muscle because other methods of estimating intracellular $\mathrm{pH}$ have been applied more extensively to muscle than to other mammalian tissues, and because changes of $\mathrm{pH}$ in muscle are of great importance in buffering on account of the large bulk of the tissue. With muscle, unlike some other tissues, it is possible to take several successive samples from a single animal during the course of an experiment without disturbing the conditions. Furthermore, there is evidence that the chloride of muscle is largely extracellular (5), and determination of the chloride space affords a method of measuring extracellular water that is convenient and probably sufficiently accurate for this purpose. Extracellular water of some other tissues cannot be estimated with as great ease or certainty.

\section{THEORETICAL CONSIDERATIONS}

Mathematical formulations. We shall consider a tissue containing intracellular water of volume $V_{1}$ and extracellular water of volume $V_{e}$, the intracellular phase being contained within membranes freely permeable to the undissociated form of a weak organic acid or base (to be called the "indicator compound"). Ve can be derived from the distribution of a substance confined to extracellular water, and $V_{1}$ from the difference between $V$. and total tissue water. Neither the intracellular nor the extracellular tissue phase is individually accessible for analysis, but the concentration, $\mathrm{C}_{t}$, of the indicator compound in the water of the entire tissue can be determined. By determinations in plasma with corrections for the Donnan equilibria, the $\mathrm{pH}$ and the concentration of the indicator compound in the extracellular tissue water $\left(\mathrm{pH}_{\mathrm{e}}\right.$ and $\mathrm{C}_{e}$, respectively) can be derived. It is assumed that the aqueous phases are homogeneous and that the indicator compound is fully equilibrated, the concentration of the undissociated form being equal in intracellular water, extracellular tissue water and plasma water. If this equality of concentration of the undissociated form is maintained regardless of $\mathrm{pH}$ differences that may exist between the two sides of the cellular membrane, it is im- material to the theory through what mechanism the $\mathrm{pH}$ gradient is brought about or whether the membrane is considered to be truly impermeable to the ionic form of the indicator compound. The apparent ionization constant and the activity coefficient of the ion are assumed to be equal in all the aqueous phases. Then, if the indicator compound is a weak organic acid with apparent ionization exponent, $\mathrm{pK}^{\prime}$, the $\mathrm{pH}$ of the intracellular water, $\mathrm{pH}_{1}$, can be expressed in terms of measurable quantities or values mathematically derived from measurable quantities :

$$
\begin{aligned}
\mathrm{pH}_{\mathrm{i}}=\mathrm{pK}^{\prime}+\log \left\{\left[\frac{\mathrm{C}_{\mathrm{t}}}{\mathrm{C}_{\mathrm{e}}}(1\right.\right. & \left.\left.+\frac{\mathrm{V}_{\mathrm{e}}}{\mathrm{V}_{\mathrm{i}}}\right)-\frac{\mathrm{V}_{\mathrm{e}}}{\mathrm{V}_{\mathrm{i}}}\right] \\
& \left.\left.\times\left[10^{\left(\mathrm{pH}_{\mathrm{e}}-\mathrm{pK}^{\prime}\right)}+1\right]-1\right\} .1\right)
\end{aligned}
$$

If the indicator compound is a weak organic base with apparent acid ionization exponent, $\mathrm{pK}_{\mathrm{a}}{ }^{\prime}$,

$$
\begin{aligned}
\mathrm{pH}_{\mathrm{i}}=\mathrm{pK}_{\mathrm{a}}{ }^{\prime}-\log \left\{\left[\frac{\mathrm{C}_{\mathrm{t}}}{\mathrm{C}_{\mathrm{e}}}\left(1+\frac{\mathrm{V}_{\mathrm{e}}}{\mathrm{V}_{\mathrm{i}}}\right)-\frac{\mathrm{V}_{\mathrm{e}}}{\mathrm{V}_{\mathrm{i}}}\right]\right. \\
\left.\times\left[10^{\left(\mathrm{pK}_{\mathrm{a}^{\prime}}-\mathrm{pH}_{\mathrm{e}}\right)}+1\right]-1\right\} .
\end{aligned}
$$

The partial derivative of the ratio $\left(\mathrm{C}_{t} / \mathrm{C}_{e}\right)$ with respect to $\mathrm{pH}_{1}$ is an index of the precision with which $\mathrm{pH}_{1}$ can be calculated from measured concentrations of the indicator compound. For an acid,

$$
\frac{\partial\left(\mathrm{C}_{\mathrm{t}} / \mathrm{C}_{\mathrm{e}}\right)}{\partial\left(\mathrm{pH}_{\mathrm{i}}\right)}=\ln 10\left(\frac{\mathrm{V}_{\mathrm{i}}}{\mathrm{V}_{\mathrm{i}}+\mathrm{V}_{\mathrm{e}}}\right)\left(\frac{10^{\mathrm{pH}_{\mathrm{i}}}}{10^{\mathrm{pH}_{\mathrm{e}}}+10^{\mathrm{pK}^{\prime}}}\right) .
$$

For a base,

$$
\frac{\partial\left(\mathrm{C}_{\mathrm{t}} / \mathrm{C}_{\mathrm{e}}\right)}{\partial\left(\mathrm{pH}_{\mathrm{i}}\right)}=-\ln 10\left(\frac{\mathrm{V}_{\mathrm{i}}}{\mathrm{V}_{\mathrm{i}}+\mathrm{V}_{\mathrm{e}}}\right)\left(\frac{10^{-\mathrm{pH}_{\mathrm{i}}}}{10^{-\mathrm{pH}_{\mathrm{e}}}+10^{-\mathrm{pK}_{\mathrm{a}^{\prime}}}}\right) .
$$

These partial derivatives as functions of the ionization exponents of acids and bases are shown in Figures 1 and 2 , respectively. In these figures, $\mathrm{pH}_{\mathbf{0}}$ is assumed to be 7.4 and $\mathrm{pH}_{1} 7.0$ (approximately the $\mathrm{pH}_{1}$ of muscle as found in this study). The functions are without maxima, increasing to approach asymptotic limits with decreasing values of $\mathrm{pK}^{\prime}$ for acids and increasing values of $\mathrm{pK}_{\mathrm{a}}^{\prime}$ for bases. If $\mathrm{pH}_{1}$ is less than $\mathrm{pH}_{e}$, as is assumed in these figures, the limiting value is greater for a base than for an acid. The stronger an acid or a base, the more sensitive an indicator it is of intracellular pH.1 If intracellular $\mathrm{pH}$ is less than plasma $\mathrm{pH}$, a base of sufficient strength can be a more sensitive indicator than any acid.

For an acid of the strength of DMO and for the values of $\mathrm{pH}_{1}, \mathrm{pH}_{e}, \mathrm{~V}_{1}$, and $\mathrm{V}_{0}$ assumed in Figures 1 and 2, an error of 0.01 unit in the calculated value of $\mathrm{pH}_{1}$ would be introduced by an error of 1.4 per cent in the ratio $\left(C_{t} / C_{e}\right)$ or by an error of 7.7 per cent in $V_{e}$. If the ionic strength of intracellular water should differ from that of extracellular water by as much as 0.05 , the $\mathrm{pK}^{\prime}$

1 This theory is not applicable to compounds that are completely dissociated such as sulfonic acids and quaternary nitrogen compounds. 
values in the two phases as predicted by the DebyeHückel theory would differ by as much as 0.03 unit, and an error of that magnitude would be introduced in the calculated value of $\mathrm{pH}_{1}$.

The assumption made above that all aqueous phases are homogeneous is undoubtedly not altogether valid, particularly with respect to the intracellular water. If the cell interior is nonuniform with respect to $\mathrm{pH}$, or if the cells in the mass of tissue analyzed differ among themselves, the value calculated for intracellular $\mathrm{pH}$ is not a mean value in the mathematical sense. It has been termed an "aggregate" $\mathrm{pH}$ by Irving, Foster and Ferguson (6) and an "overall" $\mathrm{pH}$ by Conway and Downey (7). Despite the fact that the calculated intracellular $\mathrm{pH}$ may not have a simple mathematical significance, it is a value intermediate between the values for the regions of highest and lowest $\mathrm{pH}$ in the intracellular water of the tissue and thus furnishes some information, however limited, concerning the conditions in the cells. Of even greater interest than the calculated $\mathrm{pH}$ for the normal cell are the changes that this value undergoes under physiological and pathological conditions, for these changes can be interpreted in terms of the buffering capacity of cells and the gain or loss of hydrogen ions by the cells.

Properties to be desired in a compound to be used for measurement of intracellular $p H$ in animal tissues. To be an adequately sensitive indicator of intracellular $\mathrm{pH}$, the compound must be a sufficiently strong acid or base. An acid with $\mathrm{pK}^{\prime}$ less than about 7.0 or a base with $\mathrm{pK}_{\mathrm{a}}{ }^{\prime}$ greater than about 7.0 will be satisfactory for the physiological values assumed in Figures 1 and 2 . In concentrations that are analytically determinable the compound should produce no pronounced pharmacological effects,

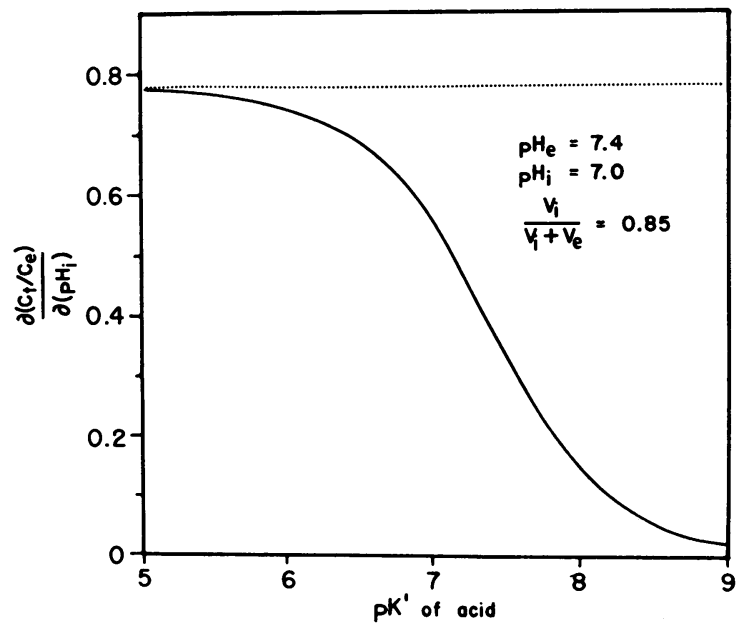

Fig. 1. The Partial Derivative of the Ratio of Concentration in total Tissue Water $\left(C_{T}\right)$ to Concentration in Extracellular Tissue Water ( $C_{E}$ ) With Respect to Intracellular $\mathrm{PH}\left(\mathrm{PH}_{1}\right)$ as A Function of the Apparent Ionization Exponent for Weak Organic Acids

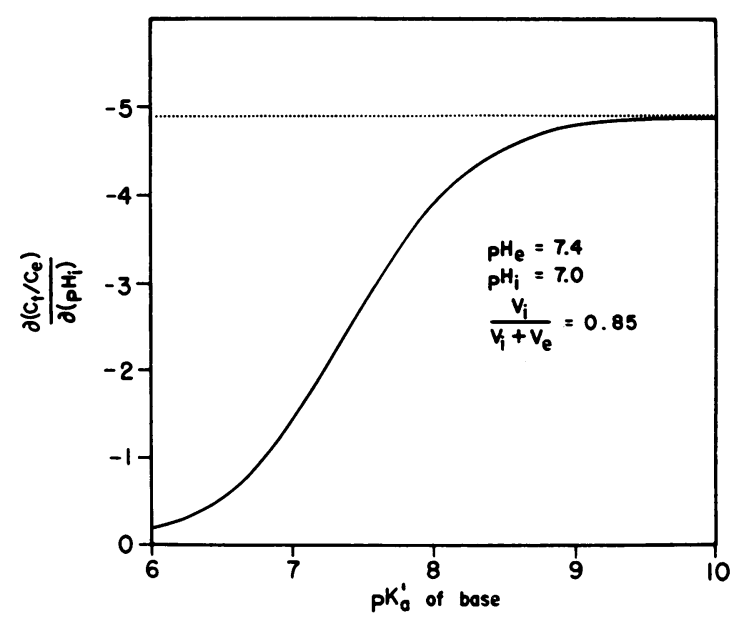

Fig. 2. The Partial Derivative of the Ratio of Concentration in Total Tissue Water $\left(C_{T}\right)$ to ConCentration in Extracellular Tissue Water $\left(\mathrm{C}_{\mathrm{E}}\right)$ With Respect to Intracellular $\mathrm{PH}\left(\mathrm{PH}_{1}\right)$ as a Function of the Apparent Acid Ionization Exponent FOR WEAK ORganic Bases

toxic or otherwise, and should not of itself affect acidbase equilibria inside or outside of cells. The compound should not interact with plasma proteins or with any constituents of the cell to a degree that would significantly affect its distribution. It should not be localized to a significant extent in nonaqueous phases of cells or plasma. Although not essential, it is desirable that the compound be slowly eliminated so that after a single dose the plasma concentration will change very little during the period required for equilibration of the compound between plasma and tissues. Finally, an analytical method must be available that is specific and sufficiently sensitive for concentrations that have no disturbing effect.

Properties of DMO. The compound is an acid with $\mathrm{pK}^{\prime}$ of 6.13 at $37^{\circ} \mathrm{C}$. and ionic strength of $0.16 . .^{2}$ As shown in Figure 1, this value of $\mathrm{pK}^{\prime}$ gives almost as sensitive an indication of intracellular $\mathrm{pH}$ as is theoretically possible for an acid. We have used plasma concentrations of DMO no higher than $250 \mu \mathrm{g}$. per $\mathrm{ml}$. in dogs for measurement of muscle $\mathrm{pH}$. There are no

2 The $\mathrm{pK}^{\prime}$ of DMO has not been measured in protein solutions. The $\mathrm{pK}_{1}{ }^{\prime}$ of carbonic acid, which is nearly equal to that of $\mathrm{DMO}$, is not affected to a great extent by the presence of protein in solutions of egg albumin, in muscle homogenates, or in erythrocyte hemolysates $(8,9)$. The assumption that the $\mathrm{pK}^{\prime}$ of $\mathrm{DMO}$ is equal in intracellular water, interstitial fluid, and plasma probably does not involve a serious error in the estimation of intracellular $\mathrm{pH}$. The error in the calculated value of $\mathrm{pH}_{1}$ contributed by an error in the value of $\mathrm{pK}^{\prime}$ for $\mathrm{DMO}$ in intracellular water is equal to the latter error and is constant. The magnitude of a change in $\mathrm{pH}_{1}$ occurring under experimental conditions would be measured without error. 
grossly observable pharmacological effects at this level, while the concentrations in plasma and muscle are high enough to permit analytical measurements of sufficient accuracy. Patients receiving trimethadione may have plasma concentrations of DMO as high as $1 \mathrm{mg}$. per $\mathrm{ml}$. without any evidence of toxic effect. DMO is not bound to plasma albumin (10). As reported in this paper, DMO is not bound to an homogenate of dog muscle to a measurable degree. The concentration of DMO in fat is very low relative to that in plasma, as evidenced by the finding that the apparent volume of distribution of DMO in omental fat of the dog is nearly equal to the chloride space and to the total volume of water of the tissue. It is unlikely that DMO is contained in lipid phases in the cell in proportions of any importance. There is no reason, then, to believe that the distribution of DMO is significantly affected by any interactions or by any localizations in nonaqueous phases that would invalidate the calculation of intracellular $\mathrm{pH}$. DMO is among the most persistent drugs that have been studied. It is not metabolized, and excretion is very slow in acid urine $(10)$. In the normal dog after equilibration, the hourly decline in plasma concentration is only about 1 to 2 per cent. For measurements of tissue $\mathrm{pH}$, a single dose of DMO can be administered to an animal, and the equilibration of tissues with plasma is not complicated by a rapidly falling plasma concentration. DMO is determinable in plasma and tissues by ultraviolet spectrophotometric methods of adequate sensitivity and of demonstrated specificity.

\section{METHODS AND MATERIALS}

Synthesis of DMO. Ethyl $\alpha$-hydroxyisobutyrate was condensed with urea in the presence of sodium ethylate by the method of Stoughton (11). DMO melts at 78 to $79^{\circ} \mathrm{C}$.

Experiments on dogs. In some early studies of the $\mathrm{pH}$ of tissues under normal conditions, dogs were anesthetized with ether or were killed by intravenous injection of air without anesthesia. In all of the experiments to be described in this report in which the effects of acidosis and alkalosis were studied, the dogs were anesthetized with $125 \mathrm{mg}$. per $\mathrm{Kg}$. of phenobarbital adminstered intravenously as a solution of the sodium salt. DMO was given intravenously in saline solution in a dose of $100 \mathrm{mg}$. per $\mathrm{Kg}$. at least an hour before the first muscle sample was taken. This time has been found to be more than sufficient for equilibration of DMO between plasma and muscle. Both renal pedicles were ligated tightly so as to occlude the renal vessels and the ureters. $\mathrm{CO}_{2}-\mathrm{O}_{2}$ mixtures were administered with an anesthetic gas machine. Overventilation was produced with a respiration pump. $\mathrm{HCl}$ was administered by slow intravenous infusion of a $0.30 \mathrm{~N}$ solution. $\mathrm{NaHCO}_{3}$ was given intravenously in 0.30 or $0.95 \mathrm{M}$ solution. Samples were taken from the muscles of the thighs. The muscle samples were blotted with cotton gauze, and all visible fat and connective tissue were trimmed away. Blood samples were taken from the femoral veins, about $3 \mathrm{mg}$. of potassium oxalate per ml. of blood being used as anticoagulant. Blood used for determination of $\mathrm{pH}$ and $\mathrm{CO}_{2}$ was handled with strict anaerobic precautions.

Total water of muscle and plasma was determined by drying weighed samples in an oven at $120^{\circ} \mathrm{C}$. for at least 12 hours. There was found to be so little variation in the water content of plasma that this determination was omitted for some samples, and the value of $0.93 \mathrm{Gm}$. per $\mathrm{Gm}$. was used in the calculations.

Determination of $D M O$. For plasma from unanesthetized dogs or dogs anesthetized with ether, the method of Butler (12) was used. For plasma from dogs anesthetized with phenobarbital the method was modified in that the extract in the buffer of $\mathrm{pH} 9.0$ was divided into two parts and the subsequent procedures were carried out as described below for the method for muscle. For muscle, a sample of 5 to $10 \mathrm{Gm}$. was homogenized with $10 \mathrm{ml}$. of distilled water with the homogenizer described in a previous study (13). A weighed sample of 1 to 3 $\mathrm{Gm}$. of the homogenate was transferred to a glass stoppered tube, in which it was shaken with $4 \mathrm{ml}$. of $5 \mathrm{M} \mathrm{NaH}_{2} \mathrm{PO}_{4}$ and $25 \mathrm{ml}$. of redistilled reagent grade absolute ethyl ether previously saturated with water. After centrifugation, $20 \mathrm{ml}$. of the ether phase was removed and extracted with $5 \mathrm{ml}$. of the borate buffer of $\mathrm{pH} 9.0$ as in the original plasma method. Of the buffer extract, $2 \mathrm{ml}$. portions were transferred to each of two tubes. To one was added $2 \mathrm{ml}$. of the buffer of $\mathrm{pH} 9.0$ and to the other $2 \mathrm{ml}$. of 0.1 $\mathrm{N} \mathrm{HCl}$. Absorbancies of both preparations were measured at 215 and $220 \mathrm{~m} \mu$, the blank for the first being the buffer, and for the second, equal volumes of buffer and $0.1 \mathrm{~N} \mathrm{HCl}$. The absorbancies at $\mathrm{pH} 9.0$ were corrected by substracting the corresponding absorbancies in acid solution. The concentration of DMO was calculated from the difference between the corrected absorbancy at $215 \mathrm{~m} \mu$ and that at $220 \mathrm{~m} \mu$. When this method was applied to muscle from dogs that had had no drug, the calculated concentrations of DMO were between 1 and $2 \mu \mathrm{g}$. per Gm. When DMO was added to normal muscle in concentrations of 50 to $100 \mu \mathrm{g}$. per $\mathrm{Gm}$., the recoveries were 96 to 104 per cent. Since the blank values are low relative to the concentrations to be determined, and since DMO is not metabolically altered in the body, the material determined as DMO in muscle can be considered to consist almost entirely of that compound. Ether and phenobarbital in anesthetic concentrations do not interfere with this method for muscle.

Determination of chloride. For plasma the method of Van Slyke and Hiller (14) was used. For muscle a sample of about $15 \mathrm{Gm}$. of the same homogenate prepared for the DMO determination was weighed into a glass stoppered graduated centrifuge tube. To the tube were added $5 \mathrm{ml}$. of a solution containing $150 \mathrm{Gm}$. of $\mathrm{Na}_{2} \mathrm{WO}_{4} \cdot 2 \mathrm{H}_{2} \mathrm{O}$ and $250 \mathrm{ml}$. of concentrated $\mathrm{H}_{3} \mathrm{PO}_{4}$ per $\mathrm{L}$., about $0.5 \mathrm{Gm}$. of $\mathrm{AgIO}_{3}$, and sufficient distilled water to make the total volume to the nearest multiple of $5 \mathrm{ml}$. The tube was shaken for $1 \mathrm{hr}$. and centrifuged. The supernatant liquid was filtered through filter paper, and a measured volume of the filtrate was titrated with thiosulfate as in the method for plasma. 
Determination of plasma $\mathrm{CO}_{2}$. Blood was centrifuged under mineral oil and the plasma $\mathrm{CO}_{2}$ was determined by the method of Van Slyke and Neill (15).

Measurement of $\mathrm{pH}$. The $\mathrm{pH}$ of blood was measured at $37^{\circ} \mathrm{C}$. by the procedure described in another report (13).

Calculations. It was assumed that Donnan equilibria prevail between plasma and extracellular tissue water for the hydrogen ion, the chloride ion, and the DMO ion. The $\mathrm{pH}$ of the extracellular tissue water, $\mathrm{pH}_{e}$, was assumed to be 0.02 unit higher than that of plasma and the concentrations of chloride and DMO ions in extracellular tissue water to be 1.05 times the corresponding concentrations in plasma water. ${ }^{3}$ On the assumption that all chloride in muscle is extracellular, the volume of extracellular water, $V_{e}$, as a proportion of total tissue weight was calculated by dividing the chloride concentration in tissue by the concentration in extracellular tissue water. The volume of intracellular water, $V_{1}$, as a proportion of total tissue weight was derived by substracting $V_{\text {. from }}$ the total proportion of water in the tissue. The concentration of DMO in extracellular tissue water, $C_{0}$, was calculated from the assumption that the concentration of the ion differes from that in plasma water by the Donnan ratio and that the concentration of undissociated form is the same in the water of the two phases. The $\mathrm{CO}_{2}$ tension of plasma was calculated from the total $\mathrm{CO}_{2}$ content of plasma and the $\mathrm{pH}$ of blood by use of the Henderson-Hasselbalch equation, the $\mathrm{pK}^{\prime}$ of carbonic acid being taken as 6.10 and the solubility coefficient, $\alpha$, of $\mathrm{CO}_{2}$ as 0.53 .

Binding of DMO to muscle homogenate. A sample of $4 \mathrm{Gm}$. of dog muscle was homogenized with $15 \mathrm{ml}$. of $0.2 \mathrm{M}$ phosphate buffer of $\mathrm{pH}$ 7.0. With the procedure described in an earlier report (13), this homogenate was dialyzed in a cellophane bag against a large volume of the buffer containing $100 \mu \mathrm{g}$. per ml. of DMO. The contents of the bag and of the outer chamber were analyzed for DMO by the method described above for muscle.

\section{RESULTS}

\section{Binding of DMO to muscle homogenate}

When the homogenate of dog muscle described under Methods was dialyzed at $37^{\circ} \mathrm{C}$. against a buffer of $\mathrm{pH} 7.0$ containing $100 \mu \mathrm{g}$. per $\mathrm{ml}$. of $\mathrm{DMO}$, there was no measurable binding of DMO to the homogenate.

\footnotetext{
${ }^{3}$ The value of the Donnan ratio varies with the $\mathrm{pH}$ of plasma as well as with the composition of plasma with respect to protein and inorganic ions. The value used here is a theoretical value calculated for protein-free extracellular tissue water equilibrated with plasma containing $160 \mathrm{mM}$ per $\mathrm{L}$. of anions other than protein and $17 \mathrm{mM}$ per L. of base bound to protein. Experimentally determined ratios for different ions in different plasma
}

\section{Intracellular $p H$ of dog muscle}

In 11 dogs that had received no treatment designed to disturb acid-base equilibria, of which seven had been anesthetized with $125 \mathrm{mg}$. per $\mathrm{Kg}$. of phenobarbital, two anesthetized with ether, and two killed by air embolism, the calculated intracellular $\mathrm{pH}$ values for muscle were all in the range of 6.96 to 7.10 with an average of 7.04. This total range is only of the order of magnitude of perhaps twice the expected experimental error, and no effect of anesthesia on $\mathrm{pH}$ was apparent.

The effects of various treatments altering the $\mathrm{pH}$ or the $\mathrm{pCO}_{2}$ of plasma were studied. In the experiments described below, two different treatments were applied successively to each dog. The combinations of treatments were chosen with the purpose of furnishing controlled comparisons of changes in $\mathrm{pH}$ and $\mathrm{pCO}_{2}$ under various conditions. Table I shows the analytical data and derived values from which the intracellular $\mathrm{pH}$ is calculated. In addition to the experiments described in Table I, there were eight other satisfactory experiments in which at least one of these same treatments was studied in each dog. In all of these experiments, the effects of the treatments were essentially the same as in the corresponding experiments of Table I.

In Experiment 1 of Table I a dog inhaled 30 per cent carbon dioxide, and sodium bicarbonate was later administered intravenously while the carbon dioxide inhalation was continued. As the $\mathrm{pCO}_{2}$ of venous plasma rose, the $\mathrm{pH}$ of venous blood fell by 0.43 unit and the calculated intracellular $\mathrm{pH}$ of muscle fell by 0.28 unit. Administration of $20 \mathrm{mM}$ per $\mathrm{Kg}$. of sodium bicarbonate restored the blood $\mathrm{pH}$ to its original value, but the plasma $\mathrm{pCO}_{2}$ was increased somewhat and the muscle $\mathrm{pH}$ was further lowered to 6.61 .

In Experiment 2 the same two treatments were given in reverse order. An intravenous dose of $10 \mathrm{mM}$ per $\mathrm{Kg}$. of sodium bicarbonate raised the $\mathrm{pH}$ of blood by 0.20 unit and the intracellular $\mathrm{pH}$ of muscle by 0.11 unit without significant effect

ultrafiltrates and transudates sometimes deviate significantly from theoretical values (5). There is no direct knowledge of the actual values of the ratios for the hydrogen, chloride, and DMO ions in interstitial fluid of muscle. The error in the estimation of the Donnan ratio probably does not introduce any large error in the calculation of intracellular $\mathrm{pH}$. 
TABLE I

Effects of various procedures altering acid-base equilibria in dags. Analytical data and derived values used in the calculation of intracellular $p H$ of muscle

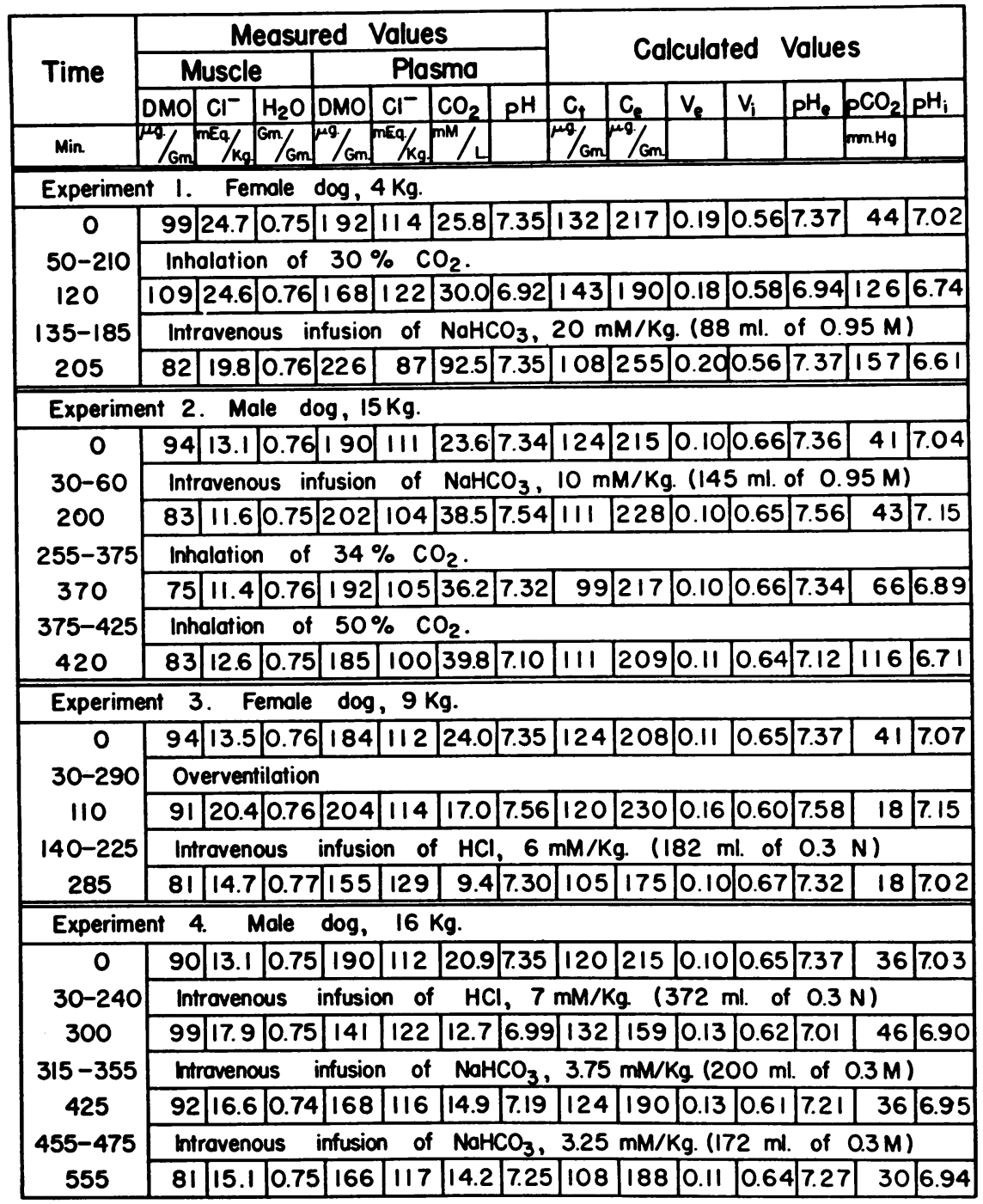

on $\mathrm{pCO}_{2}$ of plasma. Inhalation of 34 per cent carbon dioxide lowered the blood $\mathrm{pH}$ to normal while raising the plasma $\mathrm{pCO}_{2}$ and lowering the $\mathrm{pH}$ of muscle. Further increase in the inhaled concentration of carbon dioxide to 50 per cent caused additional changes in the same direction, the muscle $\mathrm{pH}$ finally reaching a value of 6.71 .

In Experiment 3 the $\mathrm{pCO}_{2}$ of plasma was lowered by overventilation with a respiration pump. Intracellular $\mathrm{pH}$ of muscle rose by 0.08 unit as the $\mathrm{pCO}_{2}$ of plasma fell and the $\mathrm{pH}$ of blood rose. Subsequently, while overventilation was continued, $6 \mathrm{mM}$ per $\mathrm{Kg}$. of hydrochloric acid was infused intravenously. The muscle $\mathrm{pH}$ as well as the blood $\mathrm{pH}$ fell somewhat below their initial levels without significant change in the plasma $\mathrm{pCO}_{2}$.

In Experiment 4 the initial treatment was an intravenous infusion of $7 \mathrm{mM}$ per $\mathrm{Kg}$. of hydrochloric acid. There was only a slight rise of plasma $\mathrm{pCO}_{2}$, which may have been due to depression of respiration consequent to deepening of phenobarbital anesthesia in acidosis (13). While the blood $\mathrm{pH}$ fell by 0.36 unit, the intracellular muscle $\mathrm{pH}$ fell by only 0.13 unit. After the injection of an equivalent amount of sodium bicarbonate, the blood $\mathrm{pH}$ rose by 0.26 unit while 
the muscle $\mathrm{pH}$ rose by only 0.04 unit, an amount that probably does not exceed the experimental error. In two other dogs in which acidosis was produced by intravenous infusion of $10 \mathrm{mM}$ per $\mathrm{Kg}$. of hydrochloric acid, the intracellular $\mathrm{pH}$ of muscle did not fall below 6.90 even though the blood $\mathrm{pH}$ in one dog fell to 6.84 .

\section{DISCUSSION}

In these experiments the largest changes in the intracellular $\mathrm{pH}$ of muscle are those brought about by increases in the carbon dioxide tension of blood. In severe metabolic acidosis with normal carbon dioxide tension the intracellular $\mathrm{pH}$ of muscle is not lowered to the extent that it is in conditions of elevated carbon dioxide tension. If the carbon dioxide tension of plasma is abnormally high, the $\mathrm{pH}$ of muscle is abnormally low even though the $\mathrm{pH}$ of blood may be normal. Both metabolic and respiratory alkalosis may cause some increase in intracellular $\mathrm{pH}$ of muscle, but the increases that can be produced by any treatment are small by comparison with the decreases resulting from increased tension of carbon dioxide.

The effect of carbon dioxide tension on the intracellular $\mathrm{pH}$ of muscle is to be expected if the muscle fibers are freely permeable to carbon dioxide, as cellular membranes in general have been found to be. That greater effects on the $\mathrm{pH}$ of muscle can be produced by raising the carbon dioxide tension above normal than by lowering it below normal is in accordance with the form of the carbon dioxide dissociation curve of muscle as described by Irving and co-workers (6). The study of Swan and Pitts (16) indicates that hydrochloric acid administered intravenously to nephrectomized dogs is neutralized in part by loss of intracellular sodium and potassium ions from tissues in exchange for hydrogen ions from extracellular water. Experiments of the same type carried out by Schwartz, Ørning and Porter (17) in dogs with intact kidneys led to similar conclusions. Tobin (18) found that intravenous hydrochloric acid in nephrectomized cats caused a shift of sodium and potassium into the extracellular space and a loss of sodium and potassium from muscle. However, in Tobin's experiments the average values of intracellular muscle $\mathrm{pH}$ as measured by the carbon dioxide method did not change after cats had received doses of 3.5 to $9.6 \mathrm{mM}$ per $\mathrm{Kg}$. of hydrochloric acid. Wallace and Hastings (19) did not find significant changes of muscle $\mathrm{pH}$ as measured by the carbon dioxide method after intravenous doses of $1 \mathrm{mM}$ per $\mathrm{Kg}$. of hydrochloric acid to cats. In our experiments in dogs the intracellular $\mathrm{pH}$ of muscle was significantly lowered by intravenous administration of hydrochloric acid, but the fall of muscle $\mathrm{pH}$ was no more than about 0.15 unit even in severe metabolic acidosis. The ionic exchanges that have been postulated to occur in metabolic acidosis apparently can operate in muscle only to the extent that intracellular buffering is sufficient to prevent any large change of intracellular $\mathrm{pH}$. Studies of the intravenous administration of sodium bicarbonate to human subjects by Singer and associates (20) and to nephrectomized dogs by Swan, Axelrod, Seip and Pitts (21) have been interpreted as indicating the disappearance of about a quarter of the injected sodium from the extracellular space. One possible mechanism that would produce this effect would be the entry of sodium ions into cells either accompanied by bicarbonate ions or in exchange for hydrogen ions. Either process would tend to raise the intracellular $\mathrm{pH}$. Wallace and Hastings (19) found no significant elevation of intracellular $\mathrm{pH}$ of muscle of cats in response to sodium bicarbonate injection. In our experiments the effects of sodium bicarbonate administration on muscle $\mathrm{pH}$ were quite small. The extent to which sodium ions may pass into muscle cells during the period of these acute experiments cannot be estimated from the present data. Intracellular buffering and possibly other mechanisms such as the intracellular production of organic acids may suffice to counteract the effect of entry of sodium to the extent that any change of $\mathrm{pH}$ may be so small as even to be difficult to detect. If the administration of sodium bicarbonate is accompanied by an increase in the carbon dioxide tension of blood, the result may actually be a decrease in the intracellular $\mathrm{pH}$ of muscle.

The values for intracellular $\mathrm{pH}$ of frog and mammalian muscle under normal conditions as measured by other workers with the carbon dioxide method have for the most part been in the range of 6.9 to 7.3. References to the earlier reports of the use of the carbon dioxide method are to be found in the review of Caldwell (2). Ad- 
ditional recent experiments in which the carbon dioxide method was used for measurement of the $\mathrm{pH}$ of mammalian muscle are those of Tobin (18) with cats and Nichols (22) with rats. Reports of the relationship between carbon dioxide tension of blood and intracellular $\mathrm{pH}$ of mammalian muscle as measured by the carbon dioxide method $(6,19$, 22) are in general accord with the results of our present experiments with the DMO method. While our experiments showed some small effect of blood $\mathrm{pH}$ on muscle $\mathrm{pH}$ aside from changes of $\mathrm{pCO}_{2}$ and those of Wallace and Hastings (19) and of Tobin (18) with the carbon dioxide method failed to do so, the results from the use of both methods are all indicative that muscle $\mathrm{pH}$ is not influenced to any great extent by blood $\mathrm{pH}$ per se. Although there has been no direct, simultaneous comparison of the two methods, it may be concluded that there is no conspicuous discrepancy between the results of the carbon dioxide method and those of the DMO method either as to the value for intracellular $\mathrm{pH}$ of normal muscle or as to the manner in which this value is affected by changes of blood chemistry.

The principal critic of the carbon dioxide method has been Conway $(1,3)$. Conway and Fearon (3) found that in alkaline extracts of muscle a large part of the acid-labile carbon dioxide is not precipitable by barium chloride. From their experiments they concluded that much of the acidlabile carbon dioxide of muscle is not bicarbonate. If the barium-soluble fraction is considered not to have come from bicarbonate in muscle, a much lower value for the calculated intracellular $\mathrm{pH}$ is obtained. The value so calculated is near 6.0 , approximately that to be expected if the hydrogen ion ratio across the cellular membrane were governed by a Donnan equilibrium. This is also approximately the $\mathrm{pH}$ value estimated by Conway (1) from a balance of the ionic charges in muscle fibers. Conway concedes that the data from which this latter calculation must be made can at present only be considered approximate.

Hill (23) has argued that a Donnan equilibrium for hydrogen ions in muscle cannot be reconciled with his experiments with frog muscle. Muscles remained excitable in media of $\mathrm{pH}$ values such that the operation of a Donnan equilibrium would have resulted in intracellular $\mathrm{pH}$ values too low to be compatible with contractility. Conway (1) has sought to refute Hill's argument in terms of the long time required for attainment of equilibrium.

In the determination by Danielson, Chu and Hastings (8) of the $\mathrm{pK}^{\prime}$ of carbonic acid in muscle brei it was found that the calculated $\mathrm{pK}^{\prime}$ values did not differ significantly among themselves in experiments in which the protein concentration and the $\mathrm{pH}$ varied over considerable ranges. These results could not have been obtained if any large part of the acid-labile carbon dioxide had been derived from a source other than bicarbonate. However, in these experiments the ground muscle had been diluted, sodium hydroxide and sodium bicarbonate had been added, and equilibration had been carried out with various tensions of carbon dioxide. Of the total carbon dioxide released by acid from the final preparations, only a small part had originally been in the muscle. An interfering substance that might constitute an important proportion of the carbon dioxide of the muscle itself might be in such small proportion in the final preparation that the effect of its presence might not exceed the experimental error. The experiments of Danielson and co-workers (8) are not, accordingly, conclusive evidence of the absence of a significant amount of acid-labile carbon dioxide other than bicarbonate in muscle.

There is no question of the chemical identity of the substance determined analytically in the DMO method. The fact that $\mathrm{pH}$ values calculated from the distribution of DMO and of carbon dioxide are in the same range supports confidence that these values are correct rather than the much lower values advocated by Conway. Whatever the chemical nature may be of the barium-soluble material in the alkaline extracts of Conway and Fearon, it appears likely that essentially all of the acidlabile carbon dioxide in the muscle cell itself is bicarbonate and that the $\mathrm{pH}$ values calculated on this assumption are correct.

The greater the number of indicator compounds found to give concordant results, the greater the confidence that can be placed in the values of intracellular $\mathrm{pH}$ calculated from the distribution of acids and bases. If unrecognized factors influence the distribution of one compound so as to invalidate the calculation of $\mathrm{pH}$, it is unlikely that the same factors will be in operation with a compound of entirely different chemical structure. Studies of a number of indicator compounds of 
diverse structures would therefore be of value. Bases would be of particular interest because they could furnish a more sensitive indication of $\mathrm{pH}$ than acids when used for tissues with intracellular $\mathrm{pH}$ values below the plasma $\mathrm{pH}$. Comparison of bases with acids would also be of interest because the errors arising from differences in $\mathrm{pK}^{\prime}$ values between intracellular and extracellular water due to differences in ionic strength would be in opposite direction for acids and bases. The only base the distribution of which has hitherto been used for calculation of intracellular $\mathrm{pH}$ is ammonia, which has the serious drawbacks of high toxicity and difficulty of analytical determination. The special requirements for a compound to be used as an indicator of intracellular $\mathrm{pH}$ exclude the great majority of known acids and bases, but a systematic search might disclose other appropriate compounds.

DMO has advantages over carbon dioxide for the measurement of intracellular $\mathrm{pH}$, and at the present time it appears to have almost ideal properties for this purpose. Although this initial study has been limited to muscle, there is no reason why the method could not be applied to any tissue in which the determination of extracellular water is feasible. The analytical method described here for DMO in muscle has been shown to be suitable also for liver and brain. Since DMO is a foreign compound that is not attacked metabolically, an application is possible that would not be possible with carbon dioxide, viz., the determination of an overall value for the intracellular $\mathrm{pH}$ of the tissues of the body as a whole. This could be carried out in human subjects since all that would be entailed would be the determination of DMO in plasma and urine after administration of a measured dose, together with simultaneous determinations of total body water and extracellular body water by means of other appropriate substances. The fact that DMO is not metabolized would also make possible the use of the isotopically labeled compound to study gradients of $\mathrm{pH}$ within small regions of a tissue or even within individual cells.

\section{SUMMARY}

The theory of estimation of intracellular $\mathrm{pH}$ by means of measurement of the distribution of weak organic acids and bases is discussed. 5,5-Di- methyl-2,4-oxazolidinedione (DMO) is shown to have properties almost ideal for this purpose.

The distribution of DMO has been used to measure the intracellular $\mathrm{pH}$ of skeletal muscle of the dog under various conditions. The intracellular $\mathrm{pH}$ of normal, resting muscle averaged 7.04. The greatest changes of $\mathrm{pH}$ of muscle are those produced by raising the carbon dioxide tension of blood. The $\mathrm{pH}$ of muscle is lowered by a high tension of carbon dioxide whether or not the blood $\mathrm{pH}$ is lowered. Metabolic acidosis has less effect in lowering muscle $\mathrm{pH}$ than does high tension of carbon dioxide. Respiratory and metabolic alkalosis raise muscle $\mathrm{pH}$ only to a small extent.

\section{REFERENCES}

1. Conway, E. J. Nature and significance of concentration relations of potassium and sodium ions in skeletal muscle. Physiol. Rev. 1957, 37, 84.

2. Caldwell, P. C. Intracellular $\mathrm{pH}$ in Int. Rev. Cytol., G. H. Bourne and J. F. Danielli, Eds. New York, Academic Press Inc., 1956, vol. 5, p. 229.

3. Conway, E. J., and Fearon, P. J. The acid-labile $\mathrm{CO}_{2}$ in mammalian muscle and the $\mathrm{pH}$ of the muscle fibre. J. Physiol. 1944, 103, 274.

4. Butler, T. C., Mahaffee, D., and Mahaffee, C. Metabolic demethylation of 3,5,5-trimethyl-2,4-oxazolidinedione (trimethadione, Tridione). Proc. Soc. exp. Biol. (N. Y.) 1952, 81, 450.

5. Manery, J. F. Water and electrolyte metabolism. Physiol. Rev. 1954, 34, 334.

6. Irving, L., Foster, H. C., and Ferguson, J. K. W. The carbon dioxide dissociation curve of living mammalian muscle. J. biol. Chem. 1932, 95, 95.

7. Conway, E. J., and Downey, M. $\mathrm{pH}$ values of the yeast cell. Biochem. J. 1950, 47, 355.

8. Danielson, I. S., Chu, H. I., and Hastings, A. B. The $\mathrm{pK}_{1}^{\prime}$ of carbonic acid in concentrated protein solutions and muscle. J. biol. Chem. 1939, 131, 243.

9. Deane, N., and Smith, H. W. The apparent first dissociation constant, $\mathrm{pK}_{1}^{\prime}$, of carbonic acid in the human erythrocyte. J. biol. Chem. 1957, 227, 101.

10. Waddell, W. J., and Butler, T. C. Renal excretion of 5,5-dimethyl-2,4-oxazolidinedione (product of demethylation of trimethadione). Proc. Soc. exp. Biol. (N. Y.) 1957, 96, 563.

11. Stoughton, R. W. 5,5-Dialkyl-2,4-oxazolidinediones. J. Amer. chem. Soc. 1941, 63, 2376.

12. Butler, T. C. Quantitative studies of the demethylation of trimethadione (Tridione). J. Pharmacol. exp. Ther. 1953, 108, 11.

13. Waddell, W. J., and Butler, T. C. The distribution and excretion of phenobarbital. J. clin. Invest. 1957, 36, 1217. 
14. Van Slyke, D. D., and Hiller, A. Application of Sendroy's iodometric chloride titration to proteincontaining fluids. J. biol. Chem. 1947, 167, 107.

15. Van Slyke, D. D., and Neill, J. M. The determination of gases in blood and other solutions by vacuum extraction and manometric measurement. I. J. biol. Chem. 1924, 61, 523.

16. Swan, R. C., and Pitts, R. F. Neutralization of infused acid by nephrectomized dogs. J. clin. Invest. 1955, 34, 205.

17. Schwartz, W. B., Ørning, K. J., and Porter, R. The internal distribution of hydrogen ions with varying degrees of metabolic acidosis. J. clin. Invest. 1957, 36,373 .

18. Tobin, R. B. Plasma, extracellular and muscle electrolyte responses to acute metabolic acidosis. Amer. J. Physiol. 1956, 186, 131.
19. Wallace, W. M., and Hastings, A. B. The distribution of the bicarbonate ion in mammalian muscle. J. biol. Chem. 1942, 144, 637.

20. Singer, R. B., Clark, J. K., Barker, E. S., Crosley, A. P., Jr., and Elkinton, J. R. The acute effects in man of rapid intravenous infusion of hypertonic sodium bicarbonate solution. I. Changes in acid-base balance and distribution of the excess buffer base. Medicine (Baltimore) 1955, 34, 51.

21. Swan, R. C., Axelrod, D. R., Seip, M., and Pitts, R. F. Distribution of sodium bicarbonate infused into nephrectomized dogs. J. clin. Invest. 1955, 34, 1795.

22. Nichols, G., Jr. Serial changes in tissue carbon dioxide content during acute respiratory acidosis. J. clin. Invest. 1958, 37, 1111.

23. Hill, A. V. The influence of the external medium on the internal $\mathrm{pH}$ of muscle. Proc. roy. Soc. B $1955,144,1$.

\section{SPECIAL NOTICE TO SUBSCRIBERS}

Post Offices will no longer forward the Journal when you move.

Please notify The Journal of Clinical Investigation, Business

Office, 333 Cedar Street, New Haven 11, Conn., at once when you have a change of address, and do not omit the zone number if there is one. 